\title{
Color, Tannin Content, and Antioxidant Potential of Dried Persimmon Fruits Prepared after Different Pretreatments
}

\section{Mun-Gyeong Cho ${ }^{1}$, Ji-Hyeong Cho ${ }^{1}$, Mun-Yeong Lee ${ }^{1}$, Sanjeev Kumar Dhungana², II-Doo Kim ${ }^{3}$}

\author{
${ }^{1}$ Agricultural Research \& Extension Services, Sangju Persimmon Research Institute, \\ Gyeongsangbukdo, Sangju 37268, Korea \\ ${ }^{2}$ School of Applied Biosciences, Kyungpook National University, Daegu 41566, Korea \\ ${ }^{3}$ International Institute of Research \& Development, Kyungpook National University, Daegu 41566, Korea
}

\begin{abstract}
Persimmon fruits are considered as one of the health promoting fruits and have long been considered as one of the major fruits in Korea. Drying is one of the most famous fruit processing techniques. The objective of this study was to investigate the effect of different pretreatments on the color, tannin content, and antioxidant potential of dried persimmon fruit. Hunter's color value of ST (dried persimmon prepared by soaking the fruits into 5\% salt solution containing $1 \%$ citric acid for $1 \mathrm{~min}$ at $65^{\circ} \mathrm{C}$ ) was significantly reduced. Although the tannin content of RB (dried persimmon prepared by spraying rice bran extracts (in $98 \%$ ethanol) and $1 \%$ citric acid for 2 min at $20^{\circ} \mathrm{C}$ ) was significantly low, the DPPH free radical scavenging potential was high at the end of drying process. The significant differences in the parameters indicated that the color value, tannin content, and antioxidant potential of dried persimmon could be remarkably affected by the pretreatment methods.
\end{abstract}

Keywords: Antioxidant, Color Value, Drying, Pretreatment, Tannin Content

\section{Introduction}

Persimmon (Diospyros kaki Thunb.), a fruit containing various health promoting substances (Lia et al., 2013; Butt et al., 2015), is grown in different parts of the world. The fruits contain different bioactive compounds, including ascorbic acids, tannins, and carotenoids, which possess good antioxidant properties (Rao and Rao, 2007; Shahkoomahally et al., 2015; Fu et al., 2016). The fruits were believed to cure various diseases, like hypertension, coughs, frostbite, paralysis, burns and bleeding (Veberic et al., 2010) in the ancient medicine. A research report (Zhang et al., 2016) shows that consumption of persimmon fruit could be beneficial for prevention of atherosclerosis. It also possesses bio-physiological functions, including hypolipidemic, arteriosclerosis prevention, anticancer and antiviral activities (Kamimoto et al., 2014). In Chinese medicine, the consumption of persimmon fruit is considered beneficial against some health problems such as coughs, hypertension, dyspnoea, paralysis, burns, and bleeding because the fruit is rich in different nutrients, including vitamin $\mathrm{C}$, vitamin $\mathrm{A}$, calcium, iron, and phenolic compounds (Nicoleti et al., 2007). An inhibitory effect of persimmon fruits on human lymphoid leukemia cells, mutagenicity of C-nitro and C-nitroso compounds (Achiwa et al.,
1997) as well as stroke and the extension of the lifespan of hypertensive rats (Uchida et al., 1995; Xie et al., 2015) have also been reported.

\begin{abstract}
Although a number of reports show that the consumption of the fruits is beneficial for human health, a regular availability of fresh fruits is difficult because it can be grown only in a particular season and in specific climatic regions. In addition, some people are reluctant to have fresh fruits (Byrne, 2002). Under such circumstances, production of high quality processed fruits of persimmon offers a good economic potential.
\end{abstract}

Among the various fruit processing technologies, drying is one of the oldest methods of food preservation (Dehydration, 1998). Persimmon fruits can be preserved by drying to allow them to be available during the off-seasons when fresh fruits could not be harvested. The dry fruits may retain many of the essential nutritional characteristics of the fresh fruits, offer reduced transportation cost, and resist against the growth of microorganisms which may deteriorate the fresh fruits (Marques et al., 2006). Astringency of some of the persimmon cultivars could also be reduced with drying. Astringency and 
color play important roles in quality characteristics of dried persimmon (Akyildiz et al., 2004).

Persimmon is processed mainly by drying. A number of reports on the effect of drying on persimmon fruits have been available. The objective of this study was to investigate the color, tannin content, and antioxidant potential of dried persimmon pretreated by different methods. This study may provide information about possibility of applying various methods of fruit pretreatment before drying.

\section{Materials and Methods}

\section{Chemicals and materials}

DPPH (2,2-diphenyl-1-picrylhydrazyl) were purchased from Sigma-Aldrich (St. Louis, MO, USA). All other reagents used were of analytical grade.

\section{Preparation of dried persimmon samples}

Persimmon (Diosyris kaki Thunb.) cv. Chungdobansi grown at Sangju Persimmon Research Institute (Sangju, Gyeongsangbuk-do, South Korea) was considered in the present study. The average weight of fruits was $200 \mathrm{~g}$ and the yield was $148-185 \mathrm{~kg}$ per tree which was quite acceptable for commercial production. The fruits were harvested at commercial maturity stage in October of 2017 and were transported to the laboratory within $6 \mathrm{~h}$ of harvest.

The fruits were washed with tap water and kept at room temperature for surface drying. The astringency of the persimmon fruits were removed by treating with ethylene gas for $24 \mathrm{~h}$ and then the fruits were peeled off manually using a peeler. The peeled fruits were cut into four pieces and subjected to different treatments before drying. The samples were named according to the treatments as control: dried persimmon prepared without any treatment; SF: dried persimmon prepared by fumigation with sulfur powder for $15 \mathrm{~min}$ at container $(1 \mathrm{~m} \times 1 \mathrm{~m} \times 1 \mathrm{~m})$; ST: dried persimmon prepared by soaking the fruits into $5 \%$ salt solution containing $1 \%$ citric acid for 1 min at $65^{\circ} \mathrm{C}$; RB: dried persimmon prepared by spraying rice bran extracts (in 98\% ethanol) and $1 \%$ citric acid for $2 \mathrm{~min}$ at $20^{\circ} \mathrm{C}$; $\mathrm{HC}$ : dried persimmon prepared by soaking in $50 \mathrm{ppm}$ sodium hypochloride for $1 \mathrm{~min}$ at $20^{\circ} \mathrm{C}$; MS: dried persimmon prepared by soaking into $0.5 \%$ sodium metabisulfite for $1 \mathrm{~min}$ at $20^{\circ} \mathrm{C}$; AC: dried persimmon prepared by soaking into $1 \% \mathrm{~N}$-acetylcysteine for $1 \mathrm{~min}$ at $20^{\circ} \mathrm{C}$. The treated fruits were dried at room temperature.

\section{Color measurement}

Hunter's color value in terms of $\mathrm{L}^{*}$ (lightness), $\mathrm{a}^{*}$ (redness, + or greenness, - ), and $\mathrm{b}^{*}$ (yellowness, + or blueness, -) of the dried persimmon fruits were measured using a chroma meter (CR-300; Minolta Corp, Osaka, Japan). A Minolta calibration plate
$(\mathrm{YCIE}=94.5, \mathrm{XCIE}=0.3160, \mathrm{YCIE}=0.330)$ and $\mathrm{a}$ Hunter Lab standard plate $\left(\mathrm{L}^{*}=97.51, \mathrm{a}^{*}=-0.18\right.$, $\left.b^{*}=+1.67\right)$ were used to standardize the instrument using a D65 illuminant (Kim et al., 2014). Color values were measured directly on 3 zones of the dried fruits and mean values were reported.

\section{Tannin content}

Tannin content was determined following a modified Prussian Blue assay method (Graham, 1992; Price et al., 1988). A $0.1-\mathrm{mL}$ of sample extract was added to $3 \mathrm{~mL}$ of distilled water, centrifuged at $10000 \times g$ for $15 \mathrm{~min}$, and the supernatant was collected. The phenolic compound of the fruits was determined by adding $1 \mathrm{~mL}$ of $0.016 \mathrm{M} \mathrm{K} \mathrm{K}_{3} \mathrm{Fe}(\mathrm{CN})_{6}$ in the supernatant followed immediately by addition of 1 $\mathrm{mL}$ of $0.02 \mathrm{M} \mathrm{FeCl}_{3}$ and mixing using a vortexer. After $15 \mathrm{~min}$, the absorbance value of reaction mixture was measured at $700 \mathrm{~nm}$ using a spectrophotometer (HP 8452A Diode-Array, Hewlett-Packard Co., Palo Alto, CA, USA). The phenolics content was expressed as tannins content as described earlier (Park, 1999).

\section{DPPH radical scavenging activity}

DPPH radical scavenging activity was measured following the method described by Cheung et al. (2003) with some modification. A $0.8-\mathrm{mL}$ of a 0.2 $\mathrm{mM}$ DPPH ethanol solution was mixed with $0.2 \mathrm{~mL}$ of the fruit extract using a vortexer and allowed to stand for $10 \mathrm{~min}$ at room temperature under dark condition, and then the absorbance value was measured at $520 \mathrm{~nm}$ using a microplate spectrophotometer (Multiskan GO, Thermo Fisher Scientic, Vantaa, Finland).

\section{Statistical analysis}

Data were subjected to analysis of variance (ANOVA) using SAS9.4 (SAS Institute Inc., Cary, NC, USA). Significant differences between the treatment means were separated using Tukey test at $\mathrm{p} \leq 0.05$.

\section{Results and Discussion \\ Color values of dried persimmon}

Hunter's color value of the fruits was significantly varied during the drying period with the pretreatment methods applied (Table 1). Overall result showed that the $\mathrm{L}^{*}(50.40-33.20)$, a* $(21.5-812.31)$, and $\mathrm{b}^{*}$ (54.13-18.91) values of ST was significantly low compared to other samples.

The color of dried persimmon is considered to have a vital role in the consumers' acceptability (Akyildiz et al., 2004). The fruit color changes to yellow or red based on the type and amount of carotenoid as persimmon matures, dried persimmon surface possesses more redness than unripe fruit (Kim et al., 1986). The difference in color values of ST might be 
Color, Tannin Content, and Antioxidant Potential of Dried Persimmon Fruits Prepared after Different Pretreatments

due to pretreatment of the fruits at higher temperature $\left(65^{\circ} \mathrm{C}\right)$, which could be attributed to the nonenzymatic browning reaction occurring at higher temperatures (Carcel et al., 2010).

Table 1. Hunter's color values of dried persimmon prepared by different treatments during drying

\begin{tabular}{|c|c|c|c|c|c|}
\hline \multirow{2}{*}{ Color value $^{1)}$} & \multirow{2}{*}{ Sample } & \multicolumn{4}{|c|}{ Drying periods (days) } \\
\hline & & 0 & 2 & 4 & 6 \\
\hline \multirow{7}{*}{$\mathrm{L}^{*}$} & Control & $53.59 \pm 1.20^{\mathrm{b}}$ & $42.66 \pm 1.00^{c}$ & $38.21 \pm 1.30^{\mathrm{cd}}$ & $35.17 \pm 0.17^{\mathrm{c}}$ \\
\hline & SF & $57.64 \pm 1.85^{\mathrm{a}}$ & $53.33 \pm 1.25^{\mathrm{a}}$ & $41.12 \pm 1.20^{\mathrm{b}}$ & $37.68 \pm 0.16^{b}$ \\
\hline & ST & $50.40 \pm 1.81^{\mathrm{c}}$ & $42.21 \pm 0.96^{\mathrm{c}}$ & $39.00 \pm 0.38^{\mathrm{c}}$ & $33.20 \pm 0.21^{\mathrm{d}}$ \\
\hline & $\mathrm{RB}$ & $56.54 \pm 1.51^{\mathrm{a}}$ & $50.17 \pm 0.88^{b}$ & $45.67 \pm 1.25^{\mathrm{a}}$ & $33.69 \pm 0.31^{\mathrm{d}}$ \\
\hline & $\mathrm{HC}$ & $58.36 \pm 1.64^{\mathrm{a}}$ & $43.67 \pm 1.62^{c}$ & $36.22 \pm 1.22^{\mathrm{d}}$ & $40.25 \pm 1.20^{\mathrm{a}}$ \\
\hline & MS & $57.74 \pm 2.14^{\mathrm{a}}$ & $43.12 \pm 1.02^{\mathrm{c}}$ & $42.13 \pm 0.25^{b}$ & $41.20 \pm 1.31^{\mathrm{a}}$ \\
\hline & $\mathrm{AC}$ & $58.32 \pm 1.02^{\mathrm{a}}$ & $48.17 \pm 1.11^{b}$ & $38.21 \pm 0.21^{\mathrm{c}}$ & $35.66 \pm 1.11^{\mathrm{c}}$ \\
\hline \multirow{7}{*}{$a^{*}$} & Control & $23.13 \pm 0.28^{b}$ & $18.02 \pm 0.13^{c}$ & $18.00 \pm 0.08^{b}$ & $18.42 \pm 0.13^{c}$ \\
\hline & SF & $23.60 \pm 1.61^{\mathrm{ab}}$ & $21.77 \pm 1.00^{b}$ & $14.00 \pm 1.02^{\mathrm{d}}$ & $15.21 \pm 0.21^{\mathrm{d}}$ \\
\hline & $\mathrm{ST}$ & $21.58 \pm 1.40^{\mathrm{c}}$ & $16.21 \pm 1.17^{\mathrm{d}}$ & $12.31 \pm 1.31^{\mathrm{e}}$ & $12.41 \pm 0.70^{\mathrm{ef}}$ \\
\hline & $\mathrm{RB}$ & $26.18 \pm 1.50^{\mathrm{a}}$ & $22.31 \pm 0.21^{b}$ & $23.66 \pm 1.32^{\mathrm{a}}$ & $22.13 \pm 0.61^{\mathrm{a}}$ \\
\hline & $\mathrm{HC}$ & $25.39 \pm 1.50^{\mathrm{a}}$ & $22.00 \pm 0.51^{\mathrm{b}}$ & $14.31 \pm 0.25^{\mathrm{d}}$ & $12.23 \pm 0.52^{f}$ \\
\hline & MS & $24.29 \pm 1.80^{\mathrm{a}}$ & $23.00 \pm 0.32^{\mathrm{a}}$ & $18.71 \pm 0.71^{b}$ & $19.12 \pm 0.59^{b}$ \\
\hline & $\mathrm{AC}$ & $25.51 \pm 0.90^{\mathrm{a}}$ & $18.91 \pm 0.42^{\mathrm{c}}$ & $16.27 \pm 0.61^{\mathrm{c}}$ & $13.17 \pm 0.60^{\mathrm{e}}$ \\
\hline \multirow{7}{*}{$b^{*}$} & Control & $54.00 \pm 1.70^{\mathrm{b}}$ & $29.88 \pm 1.21^{b}$ & $25.12 \pm 0.07^{\mathrm{c}}$ & $25.81 \pm 0.51^{d}$ \\
\hline & SF & $59.01 \pm 1.87^{\mathrm{a}}$ & $45.60 \pm 1.31^{\mathrm{a}}$ & $28.71 \pm 0.08^{b}$ & $38.16 \pm 0.21^{b}$ \\
\hline & ST & $54.13 \pm 0.09^{b}$ & $26.77 \pm 0.69^{e}$ & $20.45 \pm 0.05^{\mathrm{e}}$ & $18.91 \pm 0.31^{f}$ \\
\hline & $\mathrm{RB}$ & $60.21 \pm 0.15^{\mathrm{a}}$ & $38.12 \pm 1.00^{b}$ & $38.41 \pm 0.12^{\mathrm{a}}$ & $38.66 \pm 0.09^{b}$ \\
\hline & $\mathrm{HC}$ & $60.16 \pm 0.48^{\mathrm{a}}$ & $32.96 \pm 1.31^{\mathrm{c}}$ & $22.31 \pm 0.70^{d}$ & $20.12 \pm 0.66^{\mathrm{e}}$ \\
\hline & MS & $59.19 \pm 1.02^{\mathrm{a}}$ & $46.68 \pm 1.24^{\mathrm{a}}$ & $28.98 \pm 0.69^{b}$ & $40.17 \pm 0.78^{a}$ \\
\hline & $\mathrm{AC}$ & $59.58 \pm 1.30^{\mathrm{a}}$ & $45.12 \pm 0.96^{\mathrm{a}}$ & $28.99 \pm 0.88^{b}$ & $30.02 \pm 0.31^{\mathrm{c}}$ \\
\hline
\end{tabular}

\footnotetext{
${ }^{1)}$ Samples are defined in preparation of dried persimmon samples (Materials and Methods).

${ }^{2} \mathrm{~L}^{*}$, lightness $\left(100\right.$, white; 0, black); $\mathrm{a}^{*}$, redness (-, green; +, red); $\mathrm{b}^{*}$, yellowness (-, blue; +, yellow).

${ }^{3)}$ Quoted values are means \pm SD of triplicate measurements. Values followed by different letters in the same column are significantly different $(\mathrm{p}<0.05)$.
}

\section{Tannin content of dried persimmon}

The pretreatment of persimmon fruit significantly affected the tannin content of dry fruits (Table 2). The tannin content of ST (966.02 ppm) was significantly low at onset of drying process compared to AC (1603 ppm) followed by SF (1528.38 ppm). A significantly high tannin content was found in ST $(15.16 \mathrm{ppm})$ and the control $(16.12 \mathrm{ppm})$, whereas the lowest content was found in $\mathrm{HC}(3.14 \mathrm{ppm})$ at the end of drying.

Tannins are one of the important bioactive molecules present in persimmon (Ahn et al., 2002; VázquezGutiérrez et al., 2013). Although the effect of high temperature $\left(65^{\circ} \mathrm{C}\right)$ treatment was observed on the low tannin content (Rakić et al., 2004) during the initial period of drying, the effect was not found on the final product. However, report shows that high temperature treatment adversely affects the nutritional value of the persimmon fruits since the health-benefiting effect of phytochemical like citric acid depends on temperature and is more effective at lower temperatures (Carcel et al., 2010). 
Color, Tannin Content, and Antioxidant Potential of Dried Persimmon Fruits Prepared after Different Pretreatments

Table 2. Tannin content (ppm) of dried persimmon prepared by different treatments during drying

\begin{tabular}{lcccc}
\hline \multirow{2}{*}{ Sample $^{1)}$} & \multicolumn{4}{c}{ Drying period (days) } \\
\cline { 2 - 5 } Control & 0 & 2 & 4 & 6 \\
SF & $1439.35 \pm 23.51^{\mathrm{ab}}$ & $179.11 \pm 8.91^{\mathrm{a}}$ & $50.29 \pm 2.31^{\mathrm{b}}$ & $16.12 \pm 1.23^{\mathrm{a}}$ \\
ST & $1528.38 \pm 87.75^{\mathrm{ab}}$ & $185.31 \pm 8.71^{\mathrm{a}}$ & $60.37 \pm 3.51^{\mathrm{a}}$ & $13.15 \pm 1.33^{\mathrm{b}}$ \\
RB & $966.02 \pm 15.19^{\mathrm{d}}$ & $95.22 \pm 9.81^{\mathrm{c}}$ & $51.22 \pm 4.21^{\mathrm{b}}$ & $15.16 \pm 2.11^{\mathrm{ab}}$ \\
HC & $1266.42 \pm 62.18^{\mathrm{c}}$ & $121.17 \pm 10.12^{\mathrm{b}}$ & $42.23 \pm 3.12^{\mathrm{c}}$ & $4.17 \pm 1.00^{\mathrm{d}}$ \\
MS & $1513 . .40 \pm 46.98^{\mathrm{b}}$ & $132.16 \pm 11.88^{\mathrm{b}}$ & $98.00 \pm 3.00^{\mathrm{d}}$ & $3.14 \pm 0.89^{\mathrm{e}}$ \\
AC & $1479.52 \pm 16.39^{\mathrm{b}}$ & $136.04 \pm 6.55^{\mathrm{b}}$ & $42.12 \pm 2.12^{\mathrm{c}}$ & $7.16 \pm 1.12^{\mathrm{c}}$ \\
\hline
\end{tabular}

${ }^{\mathrm{T}}$ Samples are defined in preparation of dried persimmon samples (Materials and Methods).

${ }^{2)}$ Quoted values are means \pm SD of triplicate measurements. Values followed by different letters in the same column are significantly different $(\mathrm{p}<0.05)$.

\section{DPPH radical scavenging activities}

The DPPH radical scavenging potential of persimmon fruits were not significantly $(p>0.05)$ different at the beginning of drying, however it varied significantly $(p<0.05)$ afterwards (Table 3$)$. The highest DPPH radical scavenging potential was found in RB $(59.21 \%)$ followed by $\mathrm{AC}(58.35 \%)$ at 2 days of drying. The relative value of DPPH for RB was reduced compared to the other samples except for $\mathrm{AC}$ at 4 days of drying. The DPPH value was significantly low for ST $(58.31 \%)$ at the end of drying process.

The reduced DPPH free radical scavenging of ST might be due to the pretreatment of fruits at higher temperature $\left(65^{\circ} \mathrm{C}\right)$. High temperature reduces the antioxidant potential of bioactive compounds (Yoshioka et al., 1990, Cao et al., 2006).

Table 3. DPPH radical scavenging activities (\%) of dried persimmon prepared by different treatments during drying

\begin{tabular}{lcccc}
\hline \multirow{2}{*}{ Sample $^{1)}$} & \multicolumn{4}{c}{ Drying periods (days) } \\
\cline { 2 - 5 } Control & $56.29 \pm 1.73^{\mathrm{a}}$ & $57.66 \pm 0.37^{\mathrm{b}}$ & $58.18 \pm 1.30^{\mathrm{ab}}$ & $61.17 \pm 1.35^{\mathrm{a}}$ \\
SF & $56.82 \pm 0.76^{\mathrm{a}}$ & $56.78 \pm 0.62^{\mathrm{b}}$ & $57.12 \pm 1.21^{\mathrm{ab}}$ & $61.60 \pm 1.31^{\mathrm{a}}$ \\
ST & $55.31 \pm 0.62^{\mathrm{a}}$ & $56.72 \pm 1.11^{\mathrm{b}}$ & $58.72 \pm 0.78^{\mathrm{a}}$ & $58.31 \pm 1.23^{\mathrm{b}}$ \\
RB & $55.58 \pm 0.42^{\mathrm{a}}$ & $59.21 \pm 1.20^{\mathrm{a}}$ & $52.17 \pm 0.85^{\mathrm{c}}$ & $61.17 \pm 1.64^{\mathrm{a}}$ \\
HC & $54.29 \pm 0.95^{\mathrm{a}}$ & $49.31 \pm 1.32^{\mathrm{c}}$ & $59.31 \pm 0.78^{\mathrm{a}}$ & $60.13 \pm 1.33^{\mathrm{ab}}$ \\
MS & $56.48 \pm 0.81^{\mathrm{a}}$ & $48.37 \pm 1.22^{\mathrm{c}}$ & $56.92 \pm 0.25^{\mathrm{b}}$ & $62.31 \pm 1.20^{\mathrm{a}}$ \\
AC & $55.35 \pm 1.21^{\mathrm{a}}$ & $58.35 \pm 0.55^{\mathrm{ab}}$ & $47.31 \pm 1.21^{\mathrm{d}}$ & $61.35 \pm 0.98^{\mathrm{a}}$ \\
\hline
\end{tabular}

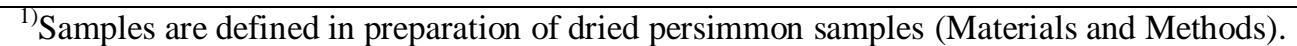

${ }^{2)}$ Quoted values are means \pm SD of triplicate measurements. Values followed by different letters in the same column are significantly different $(\mathrm{p}<0.05)$.

In conclusion, the persimmon fruits were subjected to different methods of treatment before drying in order to investigate the effect of different pretreatments on the color, tannin content, and antioxidant potential on the dry fruits. The results showed that Hunter's color value of ST (dried persimmon prepared by soaking the fruits into $5 \%$ salt solution containing $1 \%$ citric acid for $1 \mathrm{~min}$ at $65^{\circ} \mathrm{C}$ ) was significantly reduced. Although the tannin content of RB (dried persimmon prepared by spraying rice bran extracts (in $98 \%$ ethanol) and $1 \%$ citric acid for 2 min at $20^{\circ} \mathrm{C}$ ) was significantly low, the DPPH free radical scavenging potential was high at the end of drying process. The results indicated that the color value, tannin content, and antioxidant potential of dried persimmon could be affected by the pretreatment methods.

\section{References}

1. Achiwa $\mathrm{Y}$, Hibasami H, Katsuzaki H, Imai K, Komiya T (1997). Inhibitory effects of persimmon (Diospyros kaki) extract and related polyphenol compounds on growth of human lymphoid leukaemia cells. Bioscience, Biotechnology and Biochemistry. 61: 1099-1101. 
2. Ahn HS, Jeon TI, Lee JY, Hwang SG, Lim Y, Park DK (2002). Antioxidative activity of persimmon and grape seed extract: in vitro and in vivo. Nutrition Research. 22: 12651273.

3. Akyıldız A, Aksay S, Benli H, Kıroğlu F, Fenercioğlu H (2004). Determination of changes in some characteristics of persimmon during dehydration at different temperatures. Journal of Food Engineering. 65: 95-99.

4. Butt MS, Sultan MT, Aziz M, Naz A, Ahmed W, Kumar N, Imran M (2015). Persimmon (Diospyros kaki) fruit: hidden phytochemicals and health claims. EXCLI Journal. 14: 542561.

5. Byrne D H (2002). Peach breeding trends: a worldwide perspective. Acta Horticulturae. 592: 49-59.

6. Cao SF, Zheng YH, Yang ZF, Li N, Ma SJ, Tang SS, Zhang JH. Effects of storage temperature on antioxidant composition and antioxidant activity of loquat fruit. In II International Symposium on Loquat 7502006 Apr 1 (pp. 471-476).

7. Carcel JA, Perez-Garcia JV, Sansujan N, Mulet A (2010). Influence of pre-treatment and storage temperature on the evolution of the colour of dried persimmon. Food Science and Technology. 43: 1191-1196.

8. Cheung LM, Cheung PC, Ooi VE (2003). Antioxidant activity and total phenolics of edible mushroom extracts. Food Chemistry. 81: 249-255.

9. Dehydration (1998). In Encyclopaedia Britannica Online [online] Retrieved from https://global.britannica.com/topic/dehydration-foodpreservation [17 November, 2018].

10. Fu L, Lu W, Zhou X (2016). Phenolic compounds and in vitro antibacterial and antioxidant activities of three tropic fruits: persimmon, guava, and sweetsop. BioMed Research International. Article ID 4287461.

11. Graham HN (1992). Green tea composition, consumption and polyphenol chemistry. Preventive Medicine. 21: 334

12. Kamimoto M, Nakai $Y$, Tsuji T, Shimamoto T, Shimamoto T (2014). Antiviral effects of persimmon extract on human norovirus and its surrogate, bacteriophage MS2. Journal of Food Science. 79: 941-946.

13. Kim ID, Lee JW, Kim SJ, Cho JW, Dhungana SK, Lim YS, Shin DH (2014). Exogenous application of natural extracts of persimmon (Diospyros kaki Thunb.) can help in maintaining nutritional and mineral composition of dried persimmon. African Journal of Biotechnology. 3: 2231-2239.

14. Kim JH, Kim JC, Ko GC (1986). Orchard Horticulture Outline, Hyangmoonsa, Korea. pp. 220-229.

15. Lia C, Zou B, Dong X, Zhang Y, Du J (2013). Current progress on structure analysis and health benefits of persimmon tannin. Acta Horticulturae. 996: 455-466.
16. Marques LG, Silveira AM, Freire JT (2006). Freeze-drying characteristics of tropical fruits. Drying Technology. 24: 457-463.

17. Nicoleti JF, Silveira V, Tlis-Romero J, Telis VRN (2007). Influence of drying conditions on ascorbic acid during convective drying of whole persimmons. Drying Technology. 25: 891-899.

18. Park YS (1999). Carbon dioxide-induced flesh browning development as related to phenolic metabolism in 'Niitaka'pear during storage. Journal of Korean Society of Horticultural Science. 40: 567-570.

19. Price KR, Rhodes MJC, Barnes KA (1988). Flavonol glycoside content and composition of tea infusions made from commercially available teas and tea products. Journal of Agricultural and Food Chemistry. 46: 2547-2522.

20. Rakić S, Maletić RO, Perunović MN, Svrzić G (2004) Influence of thermal treatment on tannin content and antioxidation effect of oak acorn Quercus cerris extract. Journal of Agricultural Sciences, Belgrade. 49: 97-107.

21. Rao AV, Rao LG (2007). Carotenoids and human health Pharmacological Research. 55: 207-216.

22. Shahkoomahally S, Ramezanian A, Farahnaky A (2015) Postharvest nitric oxide treatment of persimmon (Diospyros $k a k i$ L.) improves fruit quality during storage. Fruits. 70: 6368.

23. Uchida S, Ozaki M, Akashi T, Ysmsdhts K, Niwa M, Taniyama K (1995). Effects of (-)-epigallocatechin-3-ogallate (green tea tannin) on the life span of stoke-prone spontaneously hypertensive rates. Clinical and Experimental Pharmacology and Physiology. 1: 302-303.

24. Vázquez-Gutiérrez JL, Hernando I, Quiles A (2013) Changes in tannin solubility and microstructure of high hydrostatic pressure-treated persimmon cubes during storage at $4^{\circ} \mathrm{C}$. European Food Research and Technology. 237: 9-17.

25. Veberic R, Jurhar J, Mikulic-Petkovsek M, Stampar F, Schmitzer V (2010). Comparative study of primary and secondary metabolites in 11 cultivars of persimmon fruit (Diospyros kaki L.) Food Chemistry. 119: 477-483.

26. Xie C, Xie Z, Xu X, Yang D (2015). Persimmon (Diospyros $k a k i$ L.) leaves: A review on traditional uses, phytochemistry and pharmacological properties. Journal of Ethnopharmacology. 163: 229-240.

27. Yoshioka H, Tsuyumu S, Takayanagi K (1990). Radical formation during the processing of green tea. Agricultural and Biological Chemistry. 54: 203-204.

28. Zhang K, Zhang Y, Zhang M, Gu L, Liu Z, Jia J, Chen X (2016). Effects of phospholipid complexes of total flavonoids from Persimmon (Diospyros kaki L.) leaves on experimental atherosclerosis rats. Journal of Ethnopharmacology. 191: 245-253. 